\title{
Emotional Regulation in Adolescent Girls when Experiencing Menstrual Pain or Dysmenorrhea
}

\author{
Regulasi Emosi pada Remaja Putri saat Mengalami Nyeri Haid atau Dismenore
}

Lestari $^{1}$, Dyah Siti Septiningsih ${ }^{2}$

${ }^{1,2}$ Universitas Muhammadiyah Purwokerto, Indonesia

\begin{abstract}
ARTICLE INFO
Article history:

DOI:

$\underline{10.30595 / p s s h . v 2 i .99}$

Submitted: 07 Aug, 2021

Accepted: Aug 13, 2021

Published: Sept 24, 2021

Keywords:

Adolescence, Menstruation, Dysmenorrhea, Emotional

ABSTRACT

The biological pride of young women is characterized by a standard physical mechanism of menstruation or menstruation followed by pain in the lower abdomen. The pain results in psychological symptoms such as anxiety, tension, anger, or emotion. Young women who cannot regulate their feelings properly are more likely to experience severe pain or so-called dysmenorrhea. Emotional regulation is the achievement of emotional balance performed by a person either from his attitude or behavior. This study aims to examine the regulation of emotions in young women who experience dysmenorrhea during menstruation. Assessment through aspects of emotional regulation, namely emotional regulation strategies, behaviors to achieve goals, control emotional responses, and acceptance of emotional responses. This research uses qualitative research methods with a case study approach. Data retrieval was conducted through semi-structured interviews of two primary informants and four secondary informants. Credibility using triangulation of sources and methods. Data analysis using interactive model data analysis. This study's findings are that both young women's ability to regulate their emotions during menstruation can relieve severe pain or dysmenorrhea during menstruation.
\end{abstract} Regulation
This work is licensed under a Creative Commons Attribution 4.0 International License.

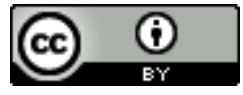

\section{Corresponding Author:}

Lestari

Universitas Muhammadiyah Purwokerto, Indonesia

Email: alestariales@gmail.com

\section{INTRODUCTION}

Adolescence lasts between 12 years to 21 years for a woman and 13 years to 22 years. The adolescent phase is a significant segment of individual development that begins with the maturity of physical organs (sexual) to reproduce typical biological changes in teenage boys and girls. One of the signs of youth that appears biologically in women is menstruation (Yusuf, 2011).

Menstruation is the decay of the uterine wall consisting of blood and body tissues; the event occurs every month and is standard for ordinary women (Saryono, 2010). Menstruation is the release of the uterine wall accompanied by bleeding that repeatedly happens every month except during pregnancy; this condition is physiological or normal in the female body and occurs periodically and is affected by reproductive hormones (Asrina, 2011).

Menstruation itself raises questions in the minds of teenage girls. First, they are unable to cope with the change; both changes also bring problems that will give rise to an emotion. What young women experience during menstruation is menstrual pain, or in medical terms called dysmenorrhea (Aden, 2010).

Dysmenorrhea is pain before, during, or after menstruation. One of the common physical symptoms during menstruation is dysmenorrhea. Complaints of menstrual pain can occur, varying from mild to severe. The severity of menstrual pain is directly related to the length and amount of menstrual blood that comes out. As is known, menstruation is almost always followed by heartburn or pain that causes easy to generate emotions Nugroho (Silvanus, 2017).

Emotional difficulties in women have little or much to do with genitalia and menstrual problems. Menstrual 
abnormalities found can be in cycles or from the amount of blood released and the length of bleeding (Asrina, 2011).

Emotional regulation is the process of receiving, maintaining, and controlling an event, the intensity and duration of perceived emotions, and physiological processes related to emotions, facial expressions, and individual behaviors that can be observed Walden \& Smith (Septi \& Jimmy, 2017).

Suppose a person has not been able to properly regulate emotions from his emotional effects on the problems they face or the main one in an individual's life well, then of course. In that case, this individual will often be so emotionally disturbed. The emotional response can be done positively, but some individuals respond to their emotions negatively (Estefan, G., \& Wijaya, 2014).

Adolescents who can regulate emotions well will control themselves when they are upset and overcome anxiety, tension, or anger. Teenagers can speed up solving problems so that pain during menstruation will decrease. This is in line with what was stated by (Khoerunisya, 2015) that the higher the emotional regulation of adolescents, the lower the pain during menstruation in adolescents. Therefore, this paper aims to provide an overview of the dynamic regulation of adolescents when experiencing menstrual pain or dysmenorrhea.

\section{THEORITICAL FRAMEWORK}

Emotion Regulation

According to (Gross, 2002) the regulation of emotions is the ability that a person has to assess, overcome, manage and express the right feelings to achieve his emotional balance so that the individual can express feelings to himself appropriately. (Shaffer, 2005) The regulation of emotions is a capacity an individual has to control and adjust emotions that arise at the right intensity to achieve a set goal. Meanwhile, (Gottman, 2003) suggests that emotional regulation is an individual's ability to prevent inappropriate behavior, calm various individual physical stimuli caused by a strong effect, focus attention, and regulate individuals to coordinate actions to achieve external goals.

According to (Gross, 2002), emotional regulation involves four aspects: emotional repression strategies, behaviors to achieve goals, control of emotional responses, and acceptance of emotional responses. In comparison, the factors that affect the regulation of emotions are (1) Health conditions, (2) Home atmosphere, (3) Parenting patterns, and (4) Guidance on controlling emotions.

\section{RESEARCH METHODOLOGY}

This study uses a qualitative research method with a case study approach. Qualitative research is research based on the collection, analysis, and achievement of narrative and visual data (not numbers) to enhance a deep understanding of a particular case of interest.

The study focused on the regulation of emotions of young women experiencing menstrual pain or dysmenorrhea. The source of the research was taken with the purposive sampling technique, a data source sampling technique with specific considerations. (Sugiyono, 2014) The study consisted of primary informants and secondary informants with specific characteristics following the research, namely the primary informant of young women who experienced menstrual pain or dysmenorrhea. Secondary informants are people who know well with primary informants, namely mothers and friends.

The data collection method in this study uses questionnaires, interviews, and observations - credibility using triangulation of sources and methods. Data analysis uses miles and Huberman interactive model data analysis (Sugiyono, 2014) : data collection, data reduction, data display, and concluding.

\section{RESULTS AND DISCUSSION}

Dysmenorrhea is pain before, during, or after menstruation. One of the common physical symptoms during menstruation is dysmenorrhea. Complaints of menstrual pain can occur, varying from mild to severe. The severity of menstrual pain is directly related to the length and amount of menstrual blood that comes out. As is known, menstruation is almost always followed by heartburn or pain that causes easy to generate emotions Nugroho (Silvanus, 2017).

Emotional difficulties in women have little or much to do with genitalia and menstrual problems. Menstrual abnormalities found can be in cycles or from the amount of blood released and the length of bleeding (Asrina, 2011). Menstrual pain will affect the emotional level of the individual during menstruation. Young women who cannot regulate their emotions properly are more likely to experience severe pain or so-called dysmenorrhea.

Emotional regulation is an individual's ability to regulate or control emotions that appear at the right level of intensity to achieve a goal. Regulation of emotions has a significant role in determining the individual's behavior; when the individual experiences negative emotions, the individual is usually unable to think clearly and perform actions outside the consciousness (Gross, 2002).

There are four aspects of emotional regulation for adolescents experiencing menstrual pain or dysmenorrhea: emotional regulation strategies, behaviors to achieve goals, controlling emotional responses and receiving emotional responses. In this study, the picture of the aspect of emotional regulation is as follows.

Regulation of emotions in menstrual pain or dysmenorrhea is conceptualized to adjust and channel negative emotions that appear to the self. This is done by emotional regulation strategies such as controlling events in the self

Proceedings homepage: https://conferenceproceedings.ump.ac.id/index.php/pssh/issue/view/7 
that cause emotions and control emotions appropriately.

Emotional awareness helps the individual control the emotions felt; thus, the individual can show an adaptive response to the perceived emotions. Lambie \& Marcel (Gross, 2002) states that basically, all individuals can be aware of their emotions from the emotional experiences they have experienced. The emotional experience is usually related to a particular situation, so the individual tends to avoid problems that can trigger the appearance of emotions.

Both informants said how to control emotions consciously; both informants chose to avoid crowds that could lead to sensitive behavior that caused negative emotions such as throwing things, crying excessively and shouting, and preferring to calm themselves down by talking to themselves, taking medicine, and giving treatment that they think can relieve pain. Reivich \& Shatte (Syahadat, 2013) say two important things related to emotional regulation: calming and focusing. Individuals who can manage both skills can help relieve existing emotions, concentrate on disturbing thoughts and reduce stress. It discusses how to overcome emotional events. Both informants can overcome the events that cause emotions by focusing on calming down, chatting with yourself, avoiding crowds, and providing treatments such as taking medications to relieve pain and feel calmer.

Cognitive reappraisal is a strategy that focuses on antecedents that occur earlier before the emotional response tendencies are fully activated and changed (Gross \& Thompson, 2007) In this study, the two informants were unable to carry out activities inside or outside the home. Like RK, the informant couldn't work because his immune system was reduced due to pain. Meanwhile, AP informants also need help from other people to carry out activities inside and outside the home, and when they are no longer able to withstand the pain they feel, they will faint.

Informants who discuss the ability to think well are also part of the behavior to achieve the goal when withstanding menstrual pain. RK informants experience cognitive decline while working; then, ap informants can also only think about how to calm down so that the pain feels reduced.

Changes in the assessment of emotional meaning by changing the mindset, keeping emotions positive is part of behavior to regulate emotions (Gross \& Thompson, 2007). Informant Rk said limiting chatting with other people and choosing to be calm and give treatment would relieve the pain. In comparison, the AP offers medical treatment and self-soothing by talking to yourself and defending yourself from being influenced by the outside not to pass out. Showing emotions appropriately can relieve pain.

In contrast to RK's informant, who couldn't stand the pain, he experienced anxiety, negative emotions emerged in throwing things and even shouting. Meanwhile, the AP informant stated that he never displayed negative emotions because when he couldn't contain his emotions and had a burden on his mind, AP would faint. (Putri \& Putri, 2020) explained that menstrual pain tends to be more frequent and more significant in adolescent girls experiencing anxiety, tension, and anxiety.

The individual's ability to balance the emotions felt and the emotional responses displayed, such as physiological responses, behavior, and tone of voice, will not feel excessive emotions and show appropriate emotional responses (Gross, 2002). In this study, RK informants had difficulty regulating the tone of voice and behavior that led to sensitive behaviors. While AP informants avoid cramps, find a comfortable place, and do selfsedation is a successful way for AP to balance emotions.

Informants who cannot accept external conditions can cause emotions, causing increased pain during menstruation. RK's informant says avoid crowded environment as it adds to the pain. The AP informant also felt that menstrual pain increased when the outside atmosphere was crowded.

The external atmosphere can influence the RK and AP informants in regulating emotions. RK is worried about others, then RK feels calm and able to regulate emotions well, but when other people ignore him, RK feels neglected and finds it difficult to regulate emotions. Unlike AP informants who get a good response from people around who give full attention and provide help, it makes us feel calm and can regulate emotions well, it is in line with the opinion (Santrock, 2011).

Teenagers with practical self-regulating skills can regulate their emotional expression in the context of generating strong emotions, such as when a friend says something negative.

Davidson, Fox, Kalin (Gross \& Thompson, 2007) suggest that emotions influence the regulation of emotions as thoughts or behaviors. When individuals experience negative emotions, individuals can usually think clearly and take actions out of consciousness. Emotional regulation is how a person can realize and regulate his thoughts and behaviors in different emotions (positive or negative).

In line with this, both informants start to accept the incident, understand themselves, be patient, and control emotions well. Both informants feel the difference in pain when menstruation becomes not easy to overflow negative emotions and do not experience fainting.

\section{CONCLUSION}

Based on the study results and discussions conducted, researchers can conclude that two young women studied can regulate their emotions during menstruation with severe pain or dysmenorrhea. Fulfilling aspects of emotional regulation can relieve severe pain during menstruation or dysmenorrhea.

Explanation based on aspects of the two informants' emotional regulation strategy can control emotions 
consciously by choosing to avoid crowds that can give rise to sensitive behaviors that cause negative emotions. Choose to focus, calm down and provide treatments that are considered to relieve pain and feel calmer.

Both informants have a way to maintain their positive emotions. When the informant has started to feel pain, both informants will provide medical and non-medical treatment such as taking medication and choose to avoid crowds to calm down so as not to touch the emotions and pain felt does not increase.

But when the informant does not get attention from people around and gets a crowded situation around, both informants will have difficulty regulating emotions that can cause increased pain and reveal negativity.

When the two informants get attention and are in a crowded situation, it will be easy for the informant to regulate his emotions. When the informant can accept the incident, understand himself, be patient, and control his emotions well, the informant will feel less pain during dysmenorrhea.

\section{REFERENCES}

Aden, R. (2010). Ketika Remaja dan Pubertas Tiba. Yogyakarta: Hanggar Keraton.

Asrina. (2011). Menstruasi dan Permasalahannya. Yogyakarta: Pustaka Panasea.

Estefan, G., \& Wijaya, Y. D. (2014). Gambaran Proses Regulasi Emosi Pada Pelaku Self-Injury. Jurnal Psikologi, 12(1), 26-33.

Gottman, John \& Declaire, J. (2003). Kiat-kiat Membesarkan Anak yang Memiliki Kecerdasan Emosional. Jakarta : PT Gramedia Pustaka Utama.

Gross, J. J., \& Thompson, R. A. (2007). Emotion Regulation: Conceptual Foundation Handbook of Emotion Regulation, edited by. James J. New York: Guilford Publications.

Gross, J. J. (2002). Emotion regulation: Affective, cognitive and social consequences. Psychophysiology, 39(3), 281291.

Khoerunisya, D. A. (2015). Hubungan Regulasi Emosi Dengan Rasa Nyeri Haid (Dismenore) Pada Remaja. Skripsi, Universitas Negeri Semarang.

Putri, N. E., \& Putri, E. A. (2020). Jurnal Nasional Ilmu Kesehatan ( JNIK ). Jurnal Nasional Ilmu Kesehatan, 3(2), 5161.

Santrock, J. W. (2011). Child Development (Perkembangan Anak Edisi 11 Jilid 2, Penerjemah: Rachmawati dan Kuswanti). Jakarta: Erlangga.

Septi T, A. Jimmy, R. \& H. B. (2017). Hubungan Mekanisme Koping dengan Regulasi Emosi Mahasiswi Semester V yang Mengalami Dismentore di Program Studi Ilmu Keperawatan Fakultas Kedokteran Universitas Sam Ratulangi. Jurnal Keperawatan UNSRAT, 5(1), 109-127.

Shaffer, D. R. (2005). Social and Personality Development. USA : Thomson.

Silvanus, Sri, M. \& Wahidyanti, R. H. (2017). Hubungan Regulasi Emosi dengan Intensitas Nyeri Dismentore Primer pada Remaja Putri di SMAN 7 Malang. Nursing News: Jurnal Ilmiah Keperawatan, 2(3), 588-600.

Sugiyono, P. D. (2014). Cara Mudah Menyusun Skripsi, Tesis, dam Disertasi (STD). Yogyakarta: Alfabeta.

Syahadat, Y. M. (2013). Pelatihan regulasi emosi untuk menurunkan perilaku agresif pada anak. Humanitas: Jurnal Psikologi Indonesia, 10(1), 19-36.

Yusuf, S. (2011). Psikologi perkembangan anak dan remaja. Bandung: PT. Remaja Rosdakarya Bandung. 